\title{
O PLANEJAMENTO LEVA À PERFEIÇÃO? OS EFEITOS DE DIFERENTES CONDIÇÕES DE PLANEJAMENTO PRÉ-TAREFA SOBRE $O$ DESEMPENHO ORAL EM L2
}

\section{DOES PLANNING MAKE PERFECT? THE EFFECTS OF DIFFERENT PRE-TASK PLANNING CONDITIONS ON L2 SPEECH PERFORMANCE}

\author{
Diêgo Cesar Leandro \\ Universidade Federal do Rio Grande do Norte, Natal, Rio Grande do Norte, Brasil \\ leandrodiegocesar@gmail.com \\ Janaina Weissheimer \\ Universidade Federal do Rio Grande do Norte, Natal, Rio Grande do Norte, Brasil \\ janaina.weissheimer@gmail.com
}

Resumo: Este artigo reporta um estudo que investigou os efeitos de diferentes condições de planejamento pré-tarefa sobre o desempenho oral em L2. Vinte e seis aprendizes de inglês de um instituto de línguas realizaram uma tarefa oral na qual tiveram de descrever três figuras, cada uma por um minuto, sob as seguintes condições: não-planejamento, planejamento oral e planejamento escrito. O desempenho oral dos participantes foi examinado em termos de fluência (speech rate unpruned e speech rate pruned), acurácia gramatical (erros por 100 palavras) e densidade lexical (proporção de palavras produzidas com propriedades gramaticais e lexicais). As medidas de produção oral foram comparadas estatisticamente de acordo com as condições de planejamento, seguindo um design intra-sujeitos. Os resultados mostram que, em geral, planejar afetou positivamente a performance oral em L2, especialmente a fluência. Os aprendizes realizaram melhor a tarefa quando tiveram pelo menos um minuto para elaborar sua fala quando comparado à condição que não dispunha de tempo de planejamento. Entretanto, ao comparar as condições oral e escrita, uma não se sobressaiu a outra, possivelmente pelo modo como foram operacionalizadas. Interpretado de outra forma, isto pode indicar que o planejamento pré-tarefa seja benéfico independentemente da forma que assuma. Este estudo de pequena escala pode contribuir para discussões teóricas acerca da produção oral em L2 e o tratamento pedagógico do planejamento oral na sala de aula de L2.

Palavras-chave: Planejamento Pré-Tarefa; Produção Oral; Inglês como L2.

Abstract: This article reports on a study which investigated the effects of different pre-task planning conditions on L2 speech performance. Twenty-six learners of English from a language institute performed an oral task in which they were required to describe three pictures, for one minute each, under the following conditions: no-planning, oral planning and written planning. Participants' oral performance was examined in terms of fluency (speech rate unpruned and speech rate pruned), grammatical accuracy (errors per 100 words) and lexical density (proportion of words produced with grammatical and lexical properties). Speech measures were statistically compared according to planning conditions, following a within-subjects design. Results show that, in general, planning has positively affected L2 oral performance, especially fluency. Learners performed better when they had at least one minute to work on their output 
when compared to having no planning time available. However, when the oral and written conditions were compared, none proved more efficient than the other, possibly due to how they were operationalized. Interpreted differently, this can be indicative of the benefit of pre-task planning, regardless of the form it takes. This small-scale study may contribute to theoretical discussions regarding second language speech production and the pedagogical treatment of speech planning in the L2 classroom.

Key-words: Pre-task Planning; Speech Production; English as an L2

\section{INTRODUCTION}

One of the objectives of research in the field of Second Language Acquisition (SLA) is to develop pedagogical strategies that may assist learners to evolve as users of an L2, for the purposes they might wish to do so. A series of studies have shown that providing the opportunity to plan usually exerts a positive impact on learners' productive skills (Foster \& Skehan, 1996; Mehnert, 1998; Ortega, 1999; D’Ely, 2006; Guará-Tavares, 2008, 2011, 2013, among others), with gains in performance even if the amount of planning time is minimal (Mehnert, 1998).

The effects of planning on L2 performance can be analyzed in a number of respects (Mehnert, 1998) and through a number of tasks (Ortega, 1999) focusing on different facets of L2 planning such as task type and complexity (Foster, 1996; Foster \& Skehan, 1996); the amount of planning time (Mehnert, 1998); planning processes (Ortega, 1999); planning for repetition (D'Ely, 2006); planning and working memory capacity (Guará-Tavares, 2011, 2013); online planning and self-repair behavior (Ahmadian, 2015); instruction on planning (Specht \& D’Ely, 2017); individual versus collaborative planning (Zaccaron, 2018), to cite but a few examples. Despite the plethora of studies, more research is needed to better understand this complex issue.

The pressure of trying to produce an L2 when one is still struggling to make sense of and master the components of a language that is not their own can be lessened by planning. This, in turn, may trigger self-awareness, leading learners to analyze their own knowledge, what they know, what they can apply and what they lack linguistically (Swain, 1985, 1993; Swain \& Lapkin, 1995). With that in mind, the purpose of this study was to investigate whether and how L2 oral performance would be affected by different pre-task ${ }^{1}$ planning conditions, instead of merely comparing unplanned and planned speech. To do so, 26 volunteer students from a language institute in the northeast of Brazil performed an oral task without planning their output and then by planning their output in verbal and written form.

The study sought to answer the following questions: a) Do different pre-task planning conditions affect L2 oral performance differently? and b) Does the oral planning condition yield more gains in speech production than the written planning condition? In order to answer these questions, performance in the three experimental conditions (no-planning, oral planning, and written planning) was compared in terms of verbal fluency, grammatical accuracy, and lexical density.

\section{THE INPUT AND OUTPUT HYPOTHESES IN SLA}

\footnotetext{
${ }^{1}$ As opposed to an online planning condition, "when there is no time pressure for task completion" (Ahmadian, 2015, p. 170).
} 
An early view on the process of acquisition/learning ${ }^{2}$ of an L2 includes the input hypothesis proposed by linguist Stephen Krashen (1981), who argues second language development occurs when the interlocutors make themselves understood during verbal interaction (Ellis, 1997); precisely when the learner is able to understand language that is a little beyond his or her current level of knowledge (Ellis, 1997; Nunan, 1999). Disregarding common sense, that means one would learn to speak by means of comprehension alone, rather than systematically attempting to speak. Moreover, Krashen stated that comprehensible input was the one necessary condition for learning an L2.

As this seemed counterintuitive, scholars went on to debate Krashen's controversial proposal (Nunan, 1999). An alternative view was put forward by Swain (1985, 1993), who argued that comprehensible input per se did not guarantee L2 native-like performance and that output had more importance in language learning than it was being given credit for. Her claims were supported by empirical research she conducted on the performance of individuals in immersion programs who, despite being exposed to comprehensible input on a daily basis for years, were not able to communicate in the target-language as competently as they should, according to Krashen's hypothesis (Swain, 1985; Swain \& Lapkin, 1995).

Swain observed that those learners communicated well enough during basic classroom interactions led by the teacher, but that they could not communicate well beyond that environment. Such limited oral proficiency was attributed to lack of opportunities to engage in meaningful extended conversation that went beyond the learners' comfort zone (Swain, 1985). Based on that finding, Swain developed the notion of comprehensible output, i.e., "output that extends the linguistic repertoire of the learner as he or she attempts to create precisely and appropriately the meaning desired" (Swain, 1985, p. 253). In other words, the output hypothesis states that it is of paramount importance that individuals trying to learn an L2 stretch their knowledge by delivering more complex messages, conveyed precisely, coherently, and appropriately (Swain, 1985).

This became a strong alternative to Krashen's input hypothesis in the field of SLA. The two insights complement each other, both providing information on how second languages are learned. One must note that Swain does not deny by any means the importance of exposure to comprehensible input, but understands that input is not the only source of learning, and that its variety and quality must be considered as well. In fact, in line with this train of thought, Schmidt (1990) pondered it was the combination of input in the classroom plus opportunities for interaction and language use out of the classroom that might facilitate and consolidate L2 learning (Schmidt \& Frota, 1986; Schmidt, 1990).

The debate on the role of input and output also deals with how exactly output could improve learning. Unsurprisingly, for Krashen (1981) the only role of output is that of becoming auto-input. Swain (1993), on the other hand, establishes more complex functions for learner output (Swain, 1993; Ellis, 1997) by considering language production not only as an opportunity to practice and gradually automatize the L2, but also to notice linguistic gaps (null or partial knowledge); to test hypotheses and to get feedback, both internal and external.

By producing language, learners can move from the semantic processing required in comprehension to the syntactic processing required for speaking. With the interplay between output functions, learners may reprocess and thus refine their language skills (Swain, 1985, 1993; Swain \& Lapkin, 1995); a goal which, in pedagogical settings, might be catalyzed by planning.

\footnotetext{
${ }^{2}$ Although the terms learning and acquisition differ conceptually, they are employed interchangeably as synonyms throughout this text.
} 


\section{THE ROLE OF PLANNING IN IMPROVING L2 SPEECH PRODUCTION}

When it comes to first-language (L1), speech production runs smoother because speakers can rely on ready-made plans for most everyday situations, in a subconscious and highly automatic manner, with reduced processing load (Mehnert, 1998). This is different in the case of an L2 because speakers must construct these plans as they go, and that requires significantly more cognitive control (Mehnert, 1998). This cognitive load can be lessened by planning (Ortega, 1999), "a metacognitive process which will be used strategically, so that learners can take advantage of time to prepare as well as to elaborate on message conceptualization and, perhaps more importantly, especially on message formulation" (D'Ely, 2006, p. 31-32).

D'Ely (2006) herself used this definition of planning while investigating the effects of the combination planning + repetition on learners' oral performance on a video-based narrative task. The oral productions of five groups of learners were analyzed in their complexity, accuracy, lexical density and fluency. Participants in the control group performed the task without planning or repeating it; participants in the strategic planning group had 10 minutes to work on their output; and participants in the repetition group performed the task twice. The other two groups combined conditions: planning plus repetition and planning for repetition.

Multifaceted results showed that planning conditions affected speech dimensions to different extents, with gains in fluency, lexical density, and accuracy for the repetition group; gains in lexical density for the planning plus repetition group; and gains in accuracy and lexical density for the planning for repetition group. This led D'Ely (2006) to argue that learners' approach to the experimental conditions was idiosyncratic and that other variables must come into play in L2 speech performance, which signaled the need for more studies on the topic of planning.

Guará-Tavares (2013) carried out research on the relationship between working memory capacity ${ }^{3}$ (WMC) and L2 performance on unplanned and planned speech. Participants ( $n=50$; intermediate level of English) were required to develop a narrative in L2 based on a set of pictures they observed for 50 seconds. Participants in the control group completed the task under a no-planning condition, telling their stories immediately after the pictures were removed. Participants in the experimental group had 10 minutes to plan their narratives prior to task performance. Statistical analyses indicated that individual differences in WMC impacted oral performance in both unplanned and planned conditions. Significant correlations were found between WMC and accuracy (number of errors per 100 words and percentage of errorfree clauses) in the no-planning condition; and between WMC, fluency (speech rate pruned and speech rate unpruned) and complexity (number of clauses per c-unit) in the planned condition.

Specht and D'Ely (2017) ponder that planning per se is not effective if learners are not instructed on how to plan. To test that hypothesis, the researchers recruited six teachers-to-be majoring in English to perform narrative tasks under the following experimental conditions: no-planning; planning before and after instruction. Performance was compared at the level of accuracy, measured as percentage of error-free clauses. Participants had 10 minutes to work on their output and, prior to performance in the third condition, they were exposed to instructional sessions on strategic planning.

Quantitative results were not statistically significant, probably due to the small sample size. Differently from the expected, instructing on how to plan did not affect L2 accuracy. However, based on a comparison between conditions, Specht and D'Ely (2017) argue that

\footnotetext{
${ }^{3}$ Working memory is "a cognitive construct responsible for the storage and processing of information and for the processes of recall and maintenance of the information acquired" (Bergsleithner, 2007, p. 10).
} 
optimizing strategic planning through instruction might lead to the production of more accurate language at some unspecified point. Qualitative results were more promising: participants stated that the instructional sessions assisted them in becoming more strategic not only when performing specific tasks, but also when speaking English in other contexts.

Based on these and other studies on planning, the present study compares three distinct pre-task planning conditions through the performance of 26 learners of English, as described in the following sections, to verify whether no-planning, oral or written planning would be more beneficial to learners.

\section{METHOD}

The present piece is an experimental, cross-sectional, within-subjects study (Dörnyei, 2007). Experimental because subjects performed lab-like tasks and their speech scores were submitted to statistical treatment; cross-sectional because speech data were collected only at one point in time, thus being a snapshot of participants' interlanguage at that point (Dörnyei, 2007); and within-subjects because all participants performed the exact same task and were compared to themselves (Miller, 1975).

\section{Participants}

Twenty-six adult learners of English integrated the cohort of the study (19 female, 7 male; age range 18 to 61 years old; mean age $=24.65$; standard deviation $=10.31$ ). Participation was strictly voluntary, and all individuals signed formal written consent before taking part in the experiment. At the time of data collection, all participants took second-year English classes at Instituto Ágora, at Universidade Federal do Rio Grande do Norte (UFRN). Fourteen participants had previously studied English at another language school, for about 11 months; and four participants had been in an English-speaking country from two weeks to a month. As exposure to the target-language was varied among participants, they were submitted to a proficiency trial focused solely on speaking skills. However, proficiency results are to be reported somewhere else, as raters were still working on them by the time this article was submitted for appraisal.

\section{Materials and procedures}

This research was approved by the Research Ethics Committee of the Federal University of Rio Grande do Norte (permit \#91755218.8.0000.5537). Data collection took place individually with each participant at Laboratório de Estudos Experimentais em Linguagem ${ }^{4}$ (LEELin), at UFRN. A smartphone was used to time the planning phase and to record the speech samples - three from each participant, thus a total of 78 samples. In order to avoid comprehension problems, task instructions were verbally given in participants' L1 (Brazilian Portuguese). The task was performed in a single session. At completion of the task, the participant was offered a bonbon, as a token of gratitude for taking the time to participate in the experiment.

\section{Picture description task and verbal measures}

\footnotetext{
${ }^{4}$ Lab for Experimental Studies in Language (LEELin-UFRN), coordinated by the second author.
} 
The experiment consisted of a picture description task aimed at eliciting speech in the L2 in different planning conditions. The task required participants to use English to describe three pictures, for one minute each, and each under a planning condition: no-planning, oral and written planning. In the no-planning condition, the same picture was presented to all participants, who started to describe it immediately after receiving the instructions. The first description served as a proficiency trial, as cited earlier. The picture depicted sportsmanship during an Olympic running competition.

In the oral and written conditions, participants made their one-minute description after planning their speech equally for one minute (Mehnert, 1998; Pang \& Skehan, 2014). This time the order of the pictures and planning conditions was counterbalanced to control for practice effects. Planning was unguided, i.e., participants were not instructed on how to plan, and no specific linguistic form was supposed to appear in their output. The pictures depicted "people doing things at home" and were taken from a sample of the B1 Preliminary English Test by the University of Cambridges.

When planning orally, participants were instructed to speak aloud in English, as if rehearsing for the moment of recording. When planning in written form, they could take notes, draw, list, draft, or doodle (Figure 1), but were not allowed to read these notes during task performance (Foster \& Skehan, 1996; Mehnert, 1998; Ortega, 1999; Mota, 2000; Specht \& D'Ely, 2017), in order to prevent them from just reading what was on paper (Specht \& D'Ely, 2017). They still had access to the picture during task performance, though.

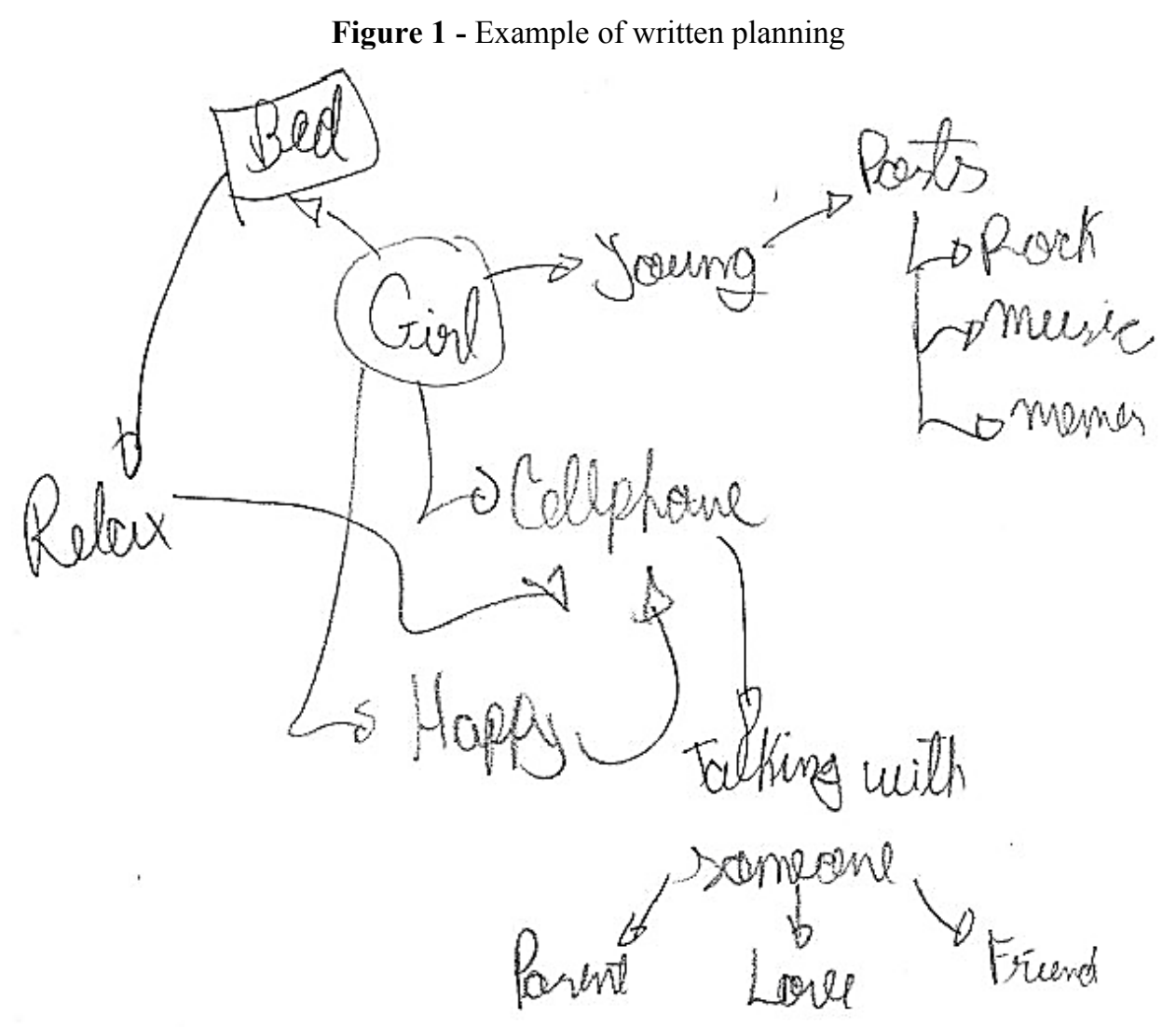

Source: the authors.

\footnotetext{
${ }^{5}$ https://www.cambridgeenglish.org/exams-and-tests/preliminary/
} 
Participants who finished planning or task performance before reaching the stipulated time of one minute were not prompted to keep speaking. Differences in total speech time were accounted for in the calculation of the two fluency-related variables.

Performance in each planning condition was analyzed in terms of the following dependent variables: grammatical accuracy, lexical density and fluency. Accuracy was operationalized as the number of errors per 100 words (Foster \& Skehan, 1996; Mehnert, 1998; Mota, 2000; Weissheimer, 2007); lexical density was operationalized as the "relationship between the number of words produced with lexical properties and the number of words produced with grammatical properties" (Weissheimer, 2007, p. 92); and fluency was measured as speech rate unpruned, "a more general measure that is assumed to reflect the relationship of articulation to silence" (Mota, 2000, p. 88) and as speech rate pruned, "[...] that reflects a more straightforward expression of ideas and unimpeded articulation of words" (Mota, 2000, p. 88). Table 1 provides a summary of the speech measures, their calculation and interpretation ${ }^{6}$.

Table 1 - Summary of speech production measures

\begin{tabular}{rll} 
Variable & \multicolumn{1}{c}{ How it was calculated } & \multicolumn{1}{c}{ What it expresses } \\
\hline $\begin{array}{r}\text { Speech rate } \\
\text { unpruned }\end{array}$ & SRU $=$ semantic units $\div$ speech time $\times 60$ & $\begin{array}{l}\text { No. of semantic units per minute; includes } \\
\text { repetitions and partial words }\end{array}$ \\
\hline $\begin{array}{r}\text { Speech rate } \\
\text { pruned }\end{array}$ & SRP $=$ semantic units $\div$ speech time $\times 60$ & $\begin{array}{l}\text { No. of semantic units per minute; only includes } \\
\text { rhetorical repetitions }\end{array}$ \\
\hline Accuracy & ACC $=$ total errors $\div$ semantic units $\times 100$ & No. of grammatical errors per 100 words \\
\hline Lexical density & $\begin{array}{l}\text { LD }=\text { weighted lexical items } \div \text { weighted } \\
\text { linguistic items } \times 100\end{array}$ & $\begin{array}{l}\text { Proportion of words produced with } \\
\text { grammatical and lexical properties }\end{array}$ \\
\hline
\end{tabular}

Source: elaborated by the authors.

\section{Analyses}

All statistical analyses were conducted using the $\mathrm{R}$ software (Winter, 2020). The confidence interval was set at $95 \%$ and the $p$-value significance at .05 in order to test the null versus the alternative hypothesis. First, measures of central tendency and data distribution were checked through histograms and boxplots. Next, the Shapiro-Wilk normality test was run, and it showed that the dataset was not entirely normally distributed, thus non-parametric tests were selected for further analyses. The effect size, measured by Cohen's $d^{7}$, was also calculated by comparing the means of the planning conditions. As for inferential statistics, the paired-sample Wilcoxon Signed-rank test was selected to compare conditions, since it was considered to be more reliable in dealing with variability in the samples.

\section{RESULTS AND DISCUSSION}

Just to reiterate, this study sought to answer two research questions: a) Do different pre-task planning conditions affect L2 oral performance differently? and b) Does the oral planning condition yield more gains in speech production than the written planning condition?

\footnotetext{
${ }^{6}$ These speech measures are detailed in the doctoral dissertations by Mota (2000), D'Ely (2006), Weissheimer (2007), Guará-Tavares (2008) and Trevisol (2019).

${ }^{7}$ Calculated using Social Science Statistics calculator: https://www.socscistatistics.com/effectsize/default3.aspx
} 
Performance was measured and compared through verbal fluency, grammatical accuracy and lexical density. The hypothesis for the first research question was that planning would yield more gains in speech performance than no-planning, a common finding in research on pre-task planning. The hypothesis for the second research question was that oral planning would outperform written planning, due to similarity with the picture description task. Table 2 provides the descriptive data and effect sizes of the speech production scores organized by planning condition, with moderate and large effect sizes (Cohen's $d>.5$ ) highlighted in bold.

Table 2 - Descriptive data and effect sizes by planning conditions

\begin{tabular}{|c|c|c|c|c|c|c|c|c|c|c|}
\hline \multirow[b]{2}{*}{ Variable } & \multirow[b]{2}{*}{$\begin{array}{c}\text { Sample } \\
\text { size }\end{array}$} & \multicolumn{2}{|c|}{ No-planning } & \multicolumn{2}{|c|}{ Oral planning } & \multicolumn{2}{|c|}{$\underline{\text { Written planning }}$} & \multicolumn{3}{|c|}{$\underline{\text { Comparisons }}$} \\
\hline & & Mean & SD & Mean & SD & Mean & SD & ES1 & ES2 & ES3 \\
\hline SRU & 26 & 45.35 & 18.09 & 59.07 & 14.50 & 59.17 & 21.17 & 0.83 & 0.70 & 0.005 \\
\hline SRP & 26 & 42.09 & 17.57 & 55.46 & 13.24 & 55.53 & 20.51 & 0.85 & 0.70 & 0.004 \\
\hline LD & 26 & 45.63 & 8.66 & 50.05 & 6.08 & 47.55 & 7.04 & 0.59 & 0.24 & 0.38 \\
\hline $\mathrm{ACC}$ & 26 & 24.01 & 17.71 & 16.78 & 7.49 & 17.87 & 6.68 & 0.53 & 0.45 & 0.15 \\
\hline
\end{tabular}

Note 1. $\mathrm{SRU}=$ Speech rate unpruned; $\mathrm{SRP}=$ Speech rate pruned; $\mathrm{LD}=$ Lexical density; $\mathrm{ACC}=$ Accuracy; $\mathrm{SD}$ $=$ standard deviation. Note 2. Effect size $(\mathrm{ES})=$ Cohen's $d$. ES1 = no-planning $\mathrm{x}$ oral; ES2 = no-planning $\mathrm{x}$ written; ES3 = oral $\mathrm{x}$ written.

Source: elaborated by the authors.

Visual inspection of the mean values indicates that all descriptors were positively affected by pre-task planning. As expected, speech planned either in the oral or written condition were relatively more fluent, more lexically dense and more accurate. Note that the expected result for accuracy was a higher mean value in the no-planning condition, since this variable expresses the number of errors one makes every 100 words. Thus, the smaller the number, the fewer errors were made in the speech sample.

As indicated by the effect sizes (ES1; ES2), fluency, as measured by speech rate unpruned (SRU) and speech rate pruned (SRP), seems to have been more affected by planning. It reached moderate to large effect sizes in both the oral and written planning conditions, with a larger effect size in the oral condition (ES1). When the oral and written conditions were compared (ES3), however, effect sizes were unsubstantial. This can be taken as indication that planning may enhance performance regardless of the form it takes.

As for inferential statistics, the no-planning condition was compared against a planned condition, a total score derived from a ratio between the scores of the oral and written conditions. Significant statistical results calculated by the Wilcoxon signed rank test were found for all speech measures, with the following values: $\operatorname{SRU}(\mathrm{p}=2.831 \mathrm{e}-07)$; $\mathrm{SRP}(\mathrm{p}=6.407 \mathrm{e}-07)$; $\operatorname{ACC}(p=0.005523)$; LD $(p=0.02804)$. That means planning was better than no-planning, as expected. The difference between planning and no-planning can be visualized in the panel of boxplots (Figure 2). 
Figure 2 - Boxpots no-planning versus planned

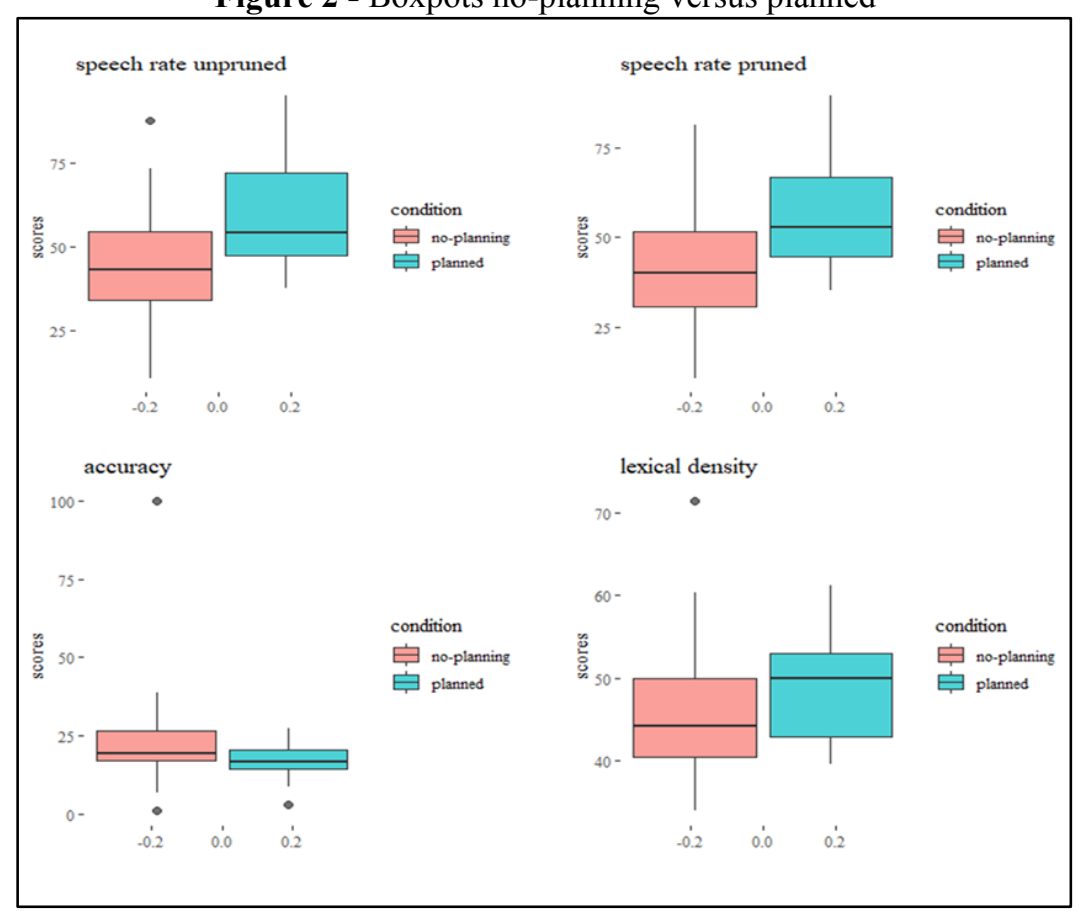

Source: the authors.

The boxplots confirm the descriptive patterns presented in Table 2, indicating that planning seems to have been a factor for improvement in speech performance. All comparisons reached statistical significance, i.e., $\mathrm{p}<.05$. Nonetheless, it is important to verify if this trend survives a statistical comparison between the three experimental conditions (Figure 3 ).

Figure 3 - Boxplots no-planning versus oral and written planning

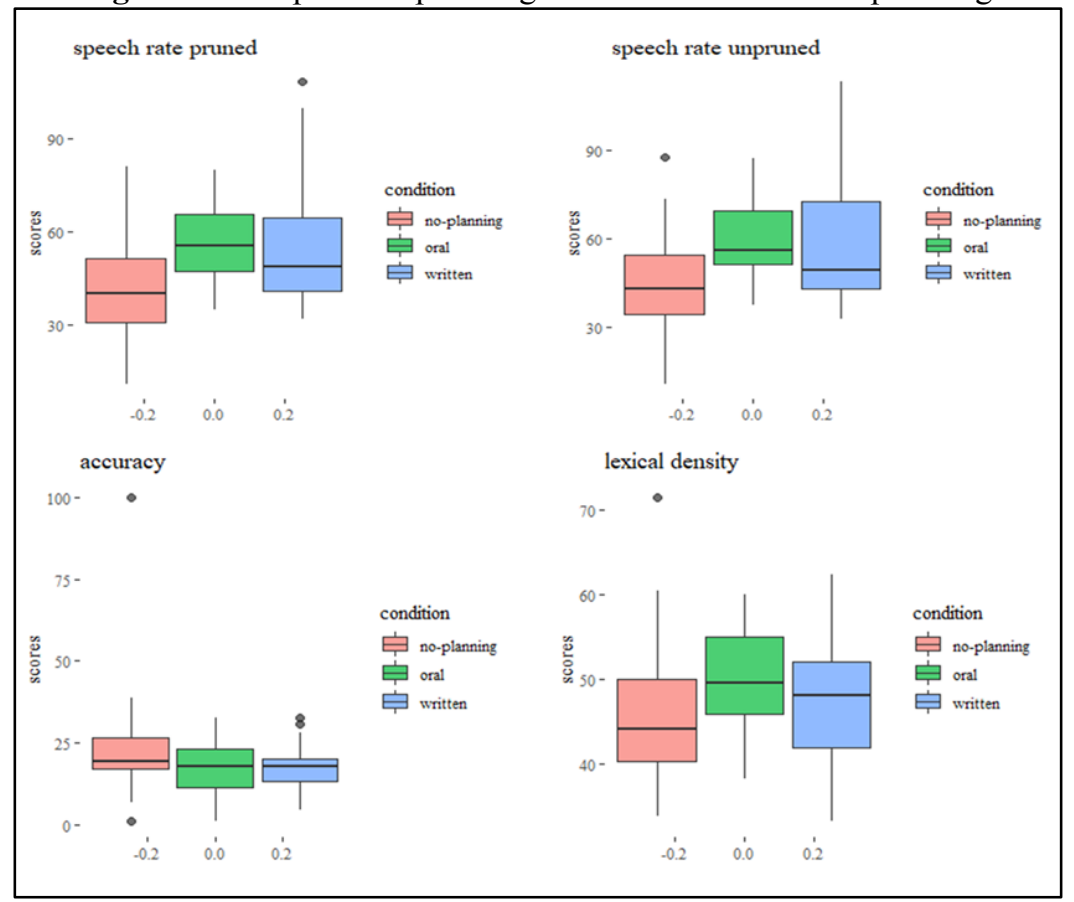

Source: the authors. 
The boxplots show the same pattern favoring planning. However, Table 3 indicates not all descriptors were truly affected by planning.

Table 3 - Wilcoxon results comparing planning conditions

\begin{tabular}{cccc}
\hline Variable & Oral x No-planning & Written x No-planning & Oral x Written \\
\hline SRU & $3.512 \mathrm{e}-05$ & $3.822 \mathrm{e}-05$ & 0.3918 \\
\hline SRP & $2.582 \mathrm{e}-05$ & $3.085 \mathrm{e}-06$ & 0.3539 \\
\hline ACC & 0.009619 & 0.01561 & 0.2114 \\
\hline LD & 0.01033 & 0.1079 & 0.05322 \\
\hline \multicolumn{4}{c}{ Source: elaborated by the authors. }
\end{tabular}

When the three planning conditions were considered, fluency (SRP; SRU) and accuracy improved in the oral and written conditions. Lexical density only improved under the oral condition. The comparison between the oral condition and the written condition did not reach statistical significance, confirming the trend indicated in Table 2 (ES3).

In general, even though learners were given only one minute to work on their output, planning proved its usefulness by leading to an increase in the number of words delivered and a decrease in the number of errors. As shown in Table 2, fluency was consistently affected in both planning conditions (ES1; ES2), but it seems to have been more affected in the oral condition, as its effect size was relatively larger (ES1). Accuracy and density also seem to have been more affected in the oral condition too, with small to moderate effect sizes. It seems plausible to argue, then, that the planning condition affects speech measures to different extents. Moreover, it seems that the oral planning condition yielded better results overall.

However, comparisons between the oral and written conditions reached no significance, going in the opposite direction of what was hypothesized: that planning orally would be more advantageous to performance due to similarity with the picture description task. Two tentative explanations: (a) this in an indication that pre-task planning is beneficial regardless of the form it assumes or (b) the amount of planning time was insufficient to make differences between conditions emerge. Mehnert's (1998) seminal study revealed that different amounts of planning time affected speech measures to different extents, but only in relation to the same planning condition. Perhaps planning condition and planning time work together to boost L2 performance.

\section{CONCLUSIONS}

In this study, it was hypothesized that the no-planning condition would be outscored by the oral and written planning conditions, and that the oral condition would outscore the written condition, as it shares more processes in common with the picture description task, since both represent the same mode. Overall, the speech measures seem to have been positively and significantly affected by pre-task planning, fluency being the most affected, given the magnitude of the effect sizes in both planning conditions.

This corroborates results of several studies (Foster \& Skehan, 1996; Mehnert, 1998; Ortega, 1999; Ellis \& Yuan, 2004, among others) that report a stronger planning effect for fluency and complexity (Guará-Tavares, 2011; Specht \& D'Ely, 2017), though the latter was not analyzed here. Although results did not clarify which planning condition is more impactful, it seems reasonable to argue that different planning conditions indeed affect speech production to different extents. Thus, the hypothesis that planning would lead to gains in L2 speech production finds support in these results. 
The hypothesis that planning orally would be more advantageous than planning by writing was not supported, since none of the comparisons between the oral and written planning conditions reached statistical significance. This was possibly due to an insufficient amount of planning time, one can speculate. We side with Guará-Tavares (2011) when she draws attention to the importance of also assessing learners' mental processes in the experiments, as a means of understanding in depth the impact of planning on performance.

\section{REFERENCES}

Ahmadian, M. J. (2015). Working Memory, Online Planning and L2 Self-Repair Behaviour. In: Wen, Z., Mota, M. B. \& McNeill, A. (Eds.), Working Memory in Second Language Acquisition and Processing. Multilingual Matters, pp. 160-174.

Bergsleithner, J. M. (2007). Working memory capacity, noticing, and L2 speech production. Unpublished doctoral dissertation. Universidade Federal de Santa Catarina.

D'Ely, R. C. S. F. (2006). A focus on learners' metacognitive processes: The impact of strategic planning, repetition, strategic planning plus repetition, and strategic planning for repetition on L2 oral performance. Unpublished doctoral dissertation. Universidade Federal de Santa Catarina.

Dörnyei, Z. (2007). Research methods in Applied Linguistics. Oxford: Oxford University Press.

Ellis, R, \& Yuan, F. (2014). The effects of planning on fluency, complexity, and accuracy in second language narrative writing. Studies in Second Language Acquisition, 26(1), 5984. Available at: www.jstor.org/stable/44486714

Ellis, R. (1997). SLA research and language teaching. Oxford: Oxford University Press.

Foster, P., \& Skehan, P. (1996). The influence of planning and task type on second language performance. Studies in Second Language Acquisition, 18, 299-323.

Foster, P. (1996). Doing the task better: how planning time influences students performance. In J. Willis, \& D. Willis (Eds.), Challenge and change in language teaching (p. 126-136). London, UK: Heinemann. 
Guará-Tavares, M. G. (2008). Pre-task planning, working memory capacity and L2 speech performance. Unpublished doctoral dissertation. Universidade Federal de Santa Catarina.

Guará-Tavares, M. G. (2011). Pre-task planning, Working Memory Capacity, and L2 speech performance. Organon 51, 245-266.

Guará-Tavares, M. G. (2013). Working memory capacity and L2 speech performance in planned and spontaneous conditions: a correlational analysis. Trab. Ling. Aplic. 52.1, 9-29.

Krashen, S.D. (1981). Second Language Acquisition and Second Language Learning. Pergamon Press Inc., Oxford.

Mehnert, U. (1998). The effects of different lengths of time for planning on second language performance. Studies on Second Language Acquisition, 20, 83-108.

Miller, S. (1975). Planejamento experimental e estatística. Tradução de Eduardo d'Almeida. Série Essential Psychology. Zahar Editores: Rio.

Mota, M. B. (2000). Working memory capacity and L2 speech production: an exploratory study. Unpublished doctoral dissertation. Universidade Federal de Santa Catarina.

Nunan, David. Second language teaching and learning. Boston: Heinle \& Heinle Publishers, 1999.

Ortega, L. (1999). Planning and focus on form in L2 oral performance. Studies in Second Language Acquisition 21(1), 109-148. Retrieved from http://www.jstor.org/stable/44486418

Pang, F., \& Skehan, P. (2014). Self-reported planning behaviour and second language performance in narrrative retelling. In P. Skehan (ed.) Processing Perspectives on Task Performance (pp. 95-128). Amsterdam: John Benjamins. 
Schmidt, R. (1990). The role of consciousness in second language learning. Applied Linguistics, $11,129-158$.

Schmidt, R., \& Frota, S. N. (1996). Developing basic conversational ability in a second language: A case study of an adult learner of Portuguese. In: Day, R. R. (Ed.), Talking to learn: Conversation in second language acquisition (pp. 237-326). Rowley, MA: Newbury House.

Specht, A. L., \& D’Ely, R. C. S. F. (2017). Planning oral narrative tasks: optimizing strategic planning condition through strategy instruction. Acta Scientiarum 39, 203-212.

Swain, M. (1985). Communicative competence: Some roles of comprehensible input and comprehensible output in its development. In: Gass S., \& Madden, C. (Eds.), Input in second language acquisition (pp. 235-253). Rowley, MA: Newbury House.

Swain, M. (1993). The Output Hypothesis: just speaking and writing aren't enough. The Canadian Modern Language Review/La Revue Canadienne des Langues Vivantes, 50, (1).

Swain, M., \& Lapkin, S. (1995). Problems in output and the cognitive processes they generate: A step towards second language learning. Applied Linguistics, 16(3), 371-391.

Trevisol, J. R. (2019). Investigating L2 learners' oral production and perception of a cycle of tasks with digital storytelling: an exploratory study in technology-mediated TBLT. Unpublished doctoral dissertation. Universidade Federal de Santa Catarina. Available at: https://repositorio.ufsc.br/handle/123456789/198996

Weissheimer, J. (2007). Working memory capacity and the development of L2 speech production: an exploratory study. Unpublished doctoral dissertation. Universidade Federal de Santa Catarina.

Winter, B. (2020). Statistics for linguists: An introduction using R. Routledge. 
Zaccaron, R. (2018). The more the merrier (?): The impact of individual and collaborative strategic planning on performance of an oral task by young learners of English as an L2 in Brazil. Unpublished master thesis. Universidade Federal de Santa Catarina.

Recebido em: 01 de fevereiro de 2020 Aceito em: 11 de março de 2020

Publicado em Maio de 2020 